\title{
HORMON ANABOLIK PADA OLAHRAWAN
}

\section{Oleh: Olivia Andiana}

\section{Dosen Jurusan Ilmu Keolahragaan FIK UM}

\begin{abstract}
Abstrak
Hormon anabolik mempunyai fungsi utama sebagai sintesis protein yang merangsang terjadinya pembesaran otot dan pertumbuhan beberapa jaringan kompleks dalam tubuh. Testosteron merupakan salahsatu contoh dari hormon anabolik yang merangsang proses pembesaran otot, begitu juga dengan HGH (human growth hormone) dan Insulin termasuk dalam hormon anabolic.

Sebagai hormon anabolik juga mempunyai fungsi lain sebagai mengeblok hormone katabolik (contohnya: kortisol dan progesterone). Lawan dari hormon anabolik adalah hormon katabolik yang disekresi oleh tubuh untuk melemahkan kerja jaringan otot. Tetapi antara anabolik dan katabolik hormone sama-sama diperlukan tubuh untuk menjaga homeostatis, atau regulasi dalam menstabilkan dalam tubuh. Hormon anabolik terbentuk dari anabolic steroid yang biasanya digunakan oleh para olahragawan dan binaragawan untuk meningkatkan massa otot dan meningkatkan performance, padahal anabolic steroid ini mempunyai efek samping yang merugikan dan tidak akan digunakan oleh atlit yang professional. Hormon anabolik ini bisa terbentuk secara alami dari dalam tubuh atau secara sintetik yang bisa diperoleh melalui injeksi anabolic steroid maupun obat.
\end{abstract}

Kata Kunci: hormon, anabolik

Ambisi untuk menang dalam setiap pertadingan dalam olahraga, yang merupakan kebanggaan diri sendiri, keluarga, maupun negara, menyebabkan atlet, pelatih, atau orang tua atlet dapat menghalalkan segala cara. Doping adalah pemakaian suatu zat atau penggunaan metode tertentu yang termasuk dalam kelompok zat dan metode terlarang , 2004:4). Cara yang paling sering digunakan adalah dengan meminum secara teratur obat, ramuan tetumbuhan, atau zat tertentu agar otot tubuh menjadi besar dan kuat.

Cara tersebut lebih populer disebut dengan doping, hal ini dilarang dalam dunia olahraga karena dianggap tidak jujur. Selain itu, doping juga berbahaya bagi kesehatan si atlet sebab dapat menyebabkan timbulnya suatu penyakit, cacat, bahkan kematian. Jadi, keuntungan yang didapat tidaklah seimbang dengan kerugian yang akan diderita bertahuntahun kemudian. Belum lagi kalau ketahuan, si atlet dan pembinanya harus menanggung rasa malu.

Salah satu jenis doping yang paling sering digunakan para atlet adalah obat-obatan anabolik, termasuk hormon androgenik steroid. Jenis hormon ini punya efek berbahaya, baik bagi atlet pria maupun atlet perempuan karena mengganggu keseimbangan hormon tubuh 


\section{MEDIKORA Vol. IX, No 1 Oktober 2012}

serta meningkatkan risiko terkena penyakit hati dan jantung. Selain sejumlah kerugian tadi, dampak kejiwaan yang diderita atlet pengguna doping yang ketahuan adalah suatu siksaan tersendiri. Banyak atlet pemakai doping yang menderita depresi. Oleh karena itu, hanya mereka (atlet) yang menggunakan "doping" $99 \%$ bakat, $99 \%$ keuletan, dan $99 \%$ kerja keras yang akan memenangi kompetisi (Restianti, 2006:1).

\section{PENGERTIAN HORMON ANABOLIK}

Hormon adalah pembawa pesan kimiawi dari satu sel atau kelompok sel ke sel lainnya. Hormon berfungsi untuk memberikan sinyal ke sel target yang selanjutnya akan melakukan suatu tindakan atau aktivitas tertentu (sistem kekebalan, metabolisme, reproduksi, dan lainlain) (Zein, 2007: 1). Anabolik adalah suatu fase dimana tubuh memperbaiki, membentuk, mensintesis dan mengembangkan sel-sel sebagai bagian dari proses metabolisme (Sherwood, 2002: 662). Hormon anabolik adalah suatu hormon yang memiliki kerja meningkatkan fungsi faal tubuh.

Kata steroid adalah istilah biokimia yang rnenggambarkan struktur tertentu. Semua hormon termasuk dalam steroid. Istilah anabolik artinya metabolisme konstruktif. Hal yang sebaliknya adalah katabolik. Dengan tambahan kata androgenik sehingga menjadi anabolik androgenik steroid berarti hormon yang mempunyai efek maskulinisasi (Moeloek, 2005:7).

Hormon-hormon yang termasuk dalam hormon anabolik adalah testosterone, insulin, growth hormone and IGF (Insulin-Like Growth Factors) (Kovacs, 2007:1).

Steroid anabolik dibagi dalam 2 kelompok yaitu:

1. Steroid anabolik androgenik atau Androgenic Anabolic Steroid (AAS)

2. Nonsteroid anabolik

Akhir-akhir ini pemakaian AAS di kalangan atlet banyak dipublikasi. Masyarakat umum berpikir bahwa pemakaian anabolik terutama pada atlet pemain sepak bola, lifter, dan atletik. Kenyataanya atlet cabang lain juga mempergunakannya yaitu lari, renang, gulat, balap sepeda, dan paling banyak olahraga beregu atau tim (Moeloek, 2005: 8).

\section{TESTOSTERON}

Testosteron adalah hormon yang diproduksi di kelenjar adrenal, fungsinya meliputi kinerja anabolik steroid, pengaturan libido, energi, sistem kekebalan tubuh dan perlindungan terhadap osteoporosis (Ganiswarna, 2002: 16). Rata-rata orang laki-laki sehat akan memproduksi 2 sampai 10 miligram testosterone dalam setiap harinya. (orang perempuan juga memproduksi testosteron tetapi dalam jumlah yang sangat kecil). Efek dari hormon 


\section{MEDIKORA Vol. IX, No 1 Oktober 2012}

anabolik ini dapat menjaga tubuh untuk mempertahankan protein, juga dapat membantu dalam pertumbuhan otot, tulang dan kulit. Karakteristik androgenik dari testosteron adalah berhubungan dengan sifat kelaki-lakian. Hormon ini akan berpengaruh menjadi lebih agresif dan sex drive (Cicero \& Lynn, 1990: 1).

Peningkatan hormon testosteron menurut NSCA (National Strength and Conditioning Association, USA) akan sangat dipengaruhi oleh program latihan. Biasanya kadar testosteron akan meningkat pada pagi hari dan akan menurun setelahnya. Teori ini mendukung bahwa olahraga di pagi hari akan menimbulkan efek yang lebih optimal daripada olahraga di sore hari (Kovacs, 2007: 2).

AAS adalah derivat hormon laki-laki yang disebut testosterone. Pada dasarnya terdapat 3 bentuk AAS yaitu:

1. Derivat testosteron C- I7 alkil

Bentuk ini larut dalam air dan dapat masuk melalui mulut, jadi dalam bentuk pil dan aktif'secara oral. Contohnya adalah stanozolol yang dipakai oleh Ben Johnson. Oleh karena larut dalam air, waktu yang diperlukan untuk membersihkan tubuh dari bahan tersebut dapat dikatakan singkat. Kebanyakan obat bentuk oral dapat bersih dari tubuh dalam waktu 3-4, minggu. Meskipun demikian harus diingat bahwa waktu bersihan dipengaruhi oleh dosis obat, berat badan atlet dan frekuensi pemakaian (Moeloek, 2005: $8)$.

2. Ester atau derivat 19-nortestosteron

Bentuk ini larut dalam lemak dan aktif bila disuntikan. Dengan sifat larut dalam lemak bahan ini, akan diabsorpsi dan masuk ke tempat penyimpanan lemak. Bila pemakai memobilisasi lemak dengan cara berolahraga maka AAS akan dilepaskan secara perlahanlahan. contohnya adalah Deca-Durabolin. Metabolit yang dideteksi daram urin adalah nandrolon. Metabolit inilah yang banyak ditemukan pada tes doping setelah pertandingan. Dibutuhkan waktu yang lama untuk membersihkan tubuh dari bahan tersebut, kadangkadang 6-8 bulan. oleh karena itulah pada berita akhir-akhir atlet positif doping nandrolon termasuk atlet Indonesia pada PON XIII dan XV yang lalu (Moeloek, 2005: 11).

3. Ester testosteron

Bentuk ini aktif baik secara oral maupun injeksi. Pemakaian testosteron telah dilakukan oleh Hitler pada tentaranya selama Perang Dunia kedua untuk membuat mereka tidak takut membunuh (Moeloek, 2005: 12).

Anabolik lainnya : 


\section{MEDIKORA Vol. IX, No 1 Oktober 2012}

a. Clenbuterol: Broncodil, Clenasma, Clenbutol, Contrasmina, Contraspasmin, Monores, Prontovent, Spiropent, Ventolase.

b. Zeranol.

Catatan:

Pemakaian testosteron dinyatakan positif doping bila ditemukan rasio testosteron $(\mathrm{T})$ dengan epitestosteron (E) di dalam urin melebihi 6: 1, kecuali bila rasio tersebut disebabkan oleh kondisi fisiologis atau patologis misalnya ekskresi E yang rendah, tumor yang menghasilkan androgen, defisiensi enzim (Moeloek, 2005: 12).

Bila ditemukan T/E lebih dari 6, tim medis yang berwenang akan melakukan penelitian sebelum sampel dinyatakan positif. Laporan dibuat tertulis dengan melampirkan data analisa sebelurnnya dan lanjutannya serta hasil pemeriksaan endokrin lainnya.

Bila analisis sebelumnya tidak dilakukan, tanpa pemberitahuan sebelumnya urin atlet harus diperiksa paling sedikit satu kali per bulan selama tiga bulan. Hasil analisis diragukan dalam laporan hasil. Bila atlet menolak bekerjasama dalam hal pemeriksaan maka akan dinyatakan sebagai sampel positif ( , 2004: 1).

1). Dosis Testosteron

Testosteron ini penggunaannya sangat mudah, karena ada yang dikemas dalam bentuk pil. Dosis yang diberikan berikisar antara 1 sampai 5 miligram dalam satu hari. Mengkonsumsi testosteron yang melebihi dosis diatas akan dapat menimbulkan efek samping yang berbahaya, seperti: peningkatan berat badan secara tiba-tiba, kesulitan bernapas, timbul jerawat, penyakit hati, pembengkakan pada kaki atau pergelangan kaki, penurunan HDL, tekanan darah meningkat, kerusakan hati dan kanker, nyeri-nyeri di persendian, dan juga dapat meningkatkan terjadinya cedera pada tendon, ligamen dan otot (Cicero \& Lynn, 1990: 1).

2). Dampak Pemakaian Testosteron pada Pria

Dampak negatif yang ditimbulkan akibat pemakaian testosterone dalam jumlah yang banyak atau pemakaian yang terus menerus, antara lain: testis akan menyusut, mengurangi jumlah produksi sperma, impotensi, kebotakan, sulit/nyeri saat kencing, dan pembesaran prostat (Cicero \& Lynn, 1990: 1).

3). Dampak Pemakaian Testosteron pada Wanita

Dampak negatif pemakaian testosterone pada wanita, umumnya meningkatkan sifat kelaki-lakian, seperti: pertumbuhan rambut yang berlebih di permukaan kulit, siklus 


\section{MEDIKORA Vol. IX, No 1 Oktober 2012}

menstruasi menjadi tidak teratur, pembesaran klitoris, suara menjadi lebih berat, dan penurunan ukuran payudara (Cicero \& Lynn, 1990: 1).

4). Efek Anabolik

Pada hipogonadisme pemberian testosteron menyebabkan imbangan nitrogen positif, retensi natrium, kalium, klorida dan penambahan berat badan. Sebaliknya, pada keadaan tanpa hipogonadisme, imbangan nitrogen positif ini hanya bertahan tidak lebih dari 1-2 bulan. Karena pemberian androgen pada hipogonadisme menyebabkan pembesaran otot dan penambahan berat badan, maka timbul anggapan bahwa pemberian androgen dalam dosis farmakologis pada orang normal akan membesarkan otot dan berat badan lebih dari normal. Hal ini tidak pemah berhasil dibuktikan. Beberapa sediaan androgen dibuat dengan tujuan mendapatkan sifat anaboliknya dengan sesedikit mungkin sifat androgenik. Sampai sekarang tidak ada sediaan hormon anabolik yang tidak bersifat andregenik, sebab kedua efek tersebut merupakan kerja hormon melalui reseptor yang sama tetapi dijaringan yang berbeda. Semua hormon anabolik dapat dipakai untuk terapi substitusi androgen dan semua dapat menimbulkan maskulinisasi bila dosis dan lama pengobatan cukup.

\section{GROWTH HORMONE}

Growth hormone merupakan somatotropin yang disekresi oleh kelenjar pituitary. GH ini berperan dalam pertumbuhan anak-anak, tetapi juga berhubungan dengan adaptasi otot terhadap latihan daya tahan (Fahey, 1998: 77). Saat ini banyak sekali suplement GH yang dijual di masyarakat, tetapi GH yang disekresikan oleh tubuh sangat berbeda sekali dengan GH yang di injeksikan ke dalam tubuh. Hipertropi yang disebabkan karena GH yang disekresikan oleh tubuh akan mampu meningkatkan produksi force (kemampuan untuk mengangkat berat akan menjadi lebih besar) jika dibandingkan dengan GH sintetis (Kovacs, 2007: 1).

Pengaruh GH antara lain: penurunan penggunaan energi dari glukosa, peningkatan pembongkaran lemak (lipolisis), meningkatkan sintesis protein dan meningkatkan kekebalan tubuh.

\section{INSULIN-LIKE GROWTH FACTORS}

Hormon anabolik insulin adalah hormon peptide yang disekresi oleh pankreas. Berdasarkan fungsi utamanya, insulin memicu terjadinya sintesis protein, metabolisme gula dan karbohidrat. Banyak efek dari growth hormone yang ditransportasikan melalui IGF. IGF- 


\section{MEDIKORA Vol. IX, No 1 Oktober 2012}

1 merupakan salahsatu golongan IGF yang berperan penting dalam olahraga. Karena IGF ini memegang peranan yang sangat penting dalam sintesis protein (Kovacs, 2007: 1).

\section{EPINEPHRINE}

Epinephrine adalah katekolamin yang disekresi oleh medulla adrenal dan epinephrine ini sangat penting dalam aktivitas yang berhubungan dengan strength dan power. Hormon ini akan menstimulasi pusat motorik, peripheral vascular dilator dan meningkatkan kerja enzim di otot (Kovacs, 2007: 1). Ada beberapa dampak fisiologis yang ditimbulkan dari epinephrine, antara lain: peningkatan rata-rata kontraksi otot, peningkatan tekanan darah, peningkatan cadangan energi, peningkatan aliran darah, merangsang peningkatan sekresi hormon lain (seperti: testosteron). Latihan daya tahan yang dilakukan secara berkesinambungan akan dapat meningkatkan epinephrine (Kovacs, 2007: 1).

\section{KESIMPULAN}

Hormon anabolik adalah suatu hormon yang memiliki kerja meningkatkan fungsi faal tubuh. Salah satu jenis doping yang paling sering digunakan para atlet adalah obat-obatan anabolik, termasuk hormon androgenik steroid. Jenis hormon ini punya efek berbahaya, baik bagi atlet pria maupun atlet perempuan karena mengganggu keseimbangan hormon tubuh serta meningkatkan risiko terkena penyakit hati dan jantung. Doping yang digunakan dari hormon anabolik oleh para olahragawan akan menimbulkan dampak negatif yang lebih banyak daripada dampak positifnya.

\section{DAFTAR PUSTAKA}

, 2004. Pedoman Pengawasan Doping PON XVI SUMSEL. Panitia besar.

Cicero, T. J \& Lynn H. O., 1990. Anabolic Steroids in Sport, (Online), (http://www.steroidsport.com/home, diakses tanggal 16 November 2011).

Fahey, T.D., 1998. Anabolic-androgenic steroids: mechanism of action and effects on performance. In: Encyclopedia of Sports Medicine and Science. (Online), (http://www.sportsci.org, diakses tanggal 16 November 2011).

Ganiswarna, Sulistia G., 2002. Farmakologi dan Terapi Edisi Keempat. Fakultas Kedokteran Universitas Indonesia. Jakarta.

Kovacs, Mark, 2007. Analysis of Anabolic and Catabolic Hormones, (Online), (http://www.healthfitness.com.au, diakses tanggal 16 November 2011). 


\section{MEDIKORA Vol. IX, No 1 Oktober 2012}

Moeloek, Dangsina, 2005. Doping Edisi kedua. Penerbit Media Aesculapius, Fakultas Kedokteran Universitas Indonesia. Jakarta.

Restianti, Hetti, 2006. Bahaya Doping untuk Atlet Wanita Pemakaian Hormon Akan Menyebabkan Tumbuhnya Sifat Pria, (Online), (http://www.pikiran-rakyat.com/ Pikiran Rakyat Bandung, diakses tanggal 16 November 2011).

Sherwood, L. 2002. Fisiologi Manusia dari Sel ke Sistem. Penerbit Buku Kedokteran, EGC. Jakarta.

Zein, 2007. Ultimate Nutrition Glosarry, (Online), (http://www.sportindo.com/Glosarry, diakses tanggal 16 November 2011). 